Olga M. Lizina

\title{
State of shadow economic activity in Russian regions
}

\section{KEYWORDS}

shadow economy;

region;

economic security;

corruption;

state regulation

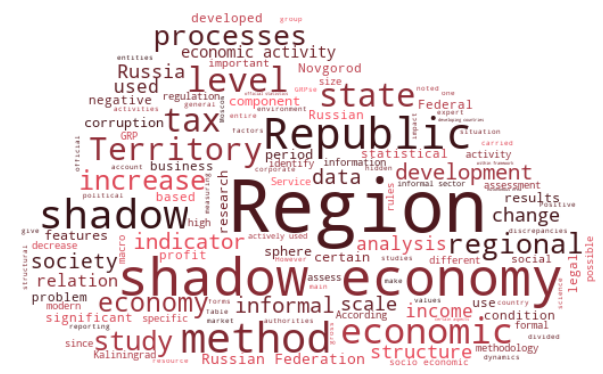

Word Cloud Generated by:

https://wordscloud.pythonanywhere.com/

\section{ABSTRACT}

Introduction. The level of the shadow economy is important for the development of any state, identifying the goals and priorities of its development. The shadow economy in Russia is the leading one among the problems that destroy the state system and pose a serious threat to national economic security.

Materials and Methods. To identify the state of the shadow economy in the Russian Federation in the context of its regions, the tax approach was used, on the basis of which the GRP indicators and components were analyzed.

Results. A comparison of statistical data with those provided by the Federal Tax Service made it possible to identify the scale of the shadow economy in Russian regions over the period from 2007 to 2018. An analysis of the data showed that from 2007 to 2009. there was a decrease in the level of the shadow economy, and, since 2009, its growth has been noted in most regions.

Conclusion. The presence of unaccounted economic activity in all Russian regions poses a threat not only to the economic security of individual regions but also to the safe and sustainable development of the entire state. Analysis of the state of the shadow economy in Russian regions showed the unevenness of its development in different regions. To conduct an effective policy of countering shadow economic processes, it is important to identify their scale and take regional characteristics into account.

Lizina, O. M. (2020). State of shadow economic activity in Russian regions. Economic consultant, 32 (4), 73-82. doi: 10.46224/ ecoc.2020.4.7 


\section{INTRODUCTION}

$\mathrm{T}$ he shadow economy is becoming one of the important factors in the destabilization of the economic, social, and political life of society. It is closely related to the legal activities of society and occupies a significant part of it. The study of the scale of the shadow economy is of great scientific and practical importance, due to its negative impact on the national economy.

The presence of shadow economic relations in any economic system is accompanied by certain socio-economic deformations: ineffectiveness of macroeconomic regulation, a reduction in budget revenues, an increase in structural crises, an increase in the tax burden, a worsening investment climate, a decrease in trust in the government and its representatives, a change in the values of society, and many others.

The problem of the shadow economy, its structure, features of functioning and development have been studied in sufficient detail by scientists from various fields of knowledge. The variety of approaches when choosing the criteria for correlating types of socio-economic activity to the shadow one explains the complexity of categorizing this phenomenon.

Initially, the concept of the informal sector of the economy, which is an attribute of most developing countries, is formed and developed in science. Hart, who was one of the first to study the shadow sector of Ghana, described the situation with the informal sector as follows: "Rejected by the structure of formal opportunities, people from the lower ranks of the urban proletariat are looking for informal ways to increase their incomes" [1].

The scale of the shadow economic activity and the criteria for its correlation may differ depending on the specifics of the macroeconomic situation and the established traditions in the country. The study of small business by Mead and Morrison carried out in 1990 in seven developing countries and covering 2,200 enterprises confirms this [2].

In Russia, the study of the shadow economy has been conducted since the 1980s, when its scale became obvious, and the imbalance in the consumer market required drastic changes. The specified problem was studied by such scientists as Koryagina [3], Nikolaeva and Shevyakov [4].

Within the framework of the study of the informal sector and informal economy, carried out by domestic researchers, studies by Gimpelson and Kapelyushnikov should be noted [5; 6], which examine in detail the issue of dualism in the labor market, presupposing its segmentation into formal and informal sectors. The conceptual foundations of unregistered activity are laid down in Latov [7-9], Barsukova [10; 11]. The studies by Kosals [12] are devoted to corruption and spread of fraud; Radaev pays attention to certain aspects of illegal traffic of products $[13 ; 14]$. The structure of financial flows of the shadow economy was analyzed by Avdiyskiy [15].

The complex structure of the shadow economy does not allow the use of universal methods to measure this phenomenon. Researchers from different countries are trying to assess the 
scale of the shadow economy in individual regions. Among foreign studies of the scale of the shadow economy, the most recognized are the works by Schneider [16; 17]. In the study of the shadow economy in 36 developed and developing countries of the European Union, a combined approach was applied, based on an econometric analysis of extensive statistical data and an analysis of the results of surveys.

Their entire set of methods can be conditionally divided into several groups:

1. Direct methods are based on inspections by the relevant authorities, interviews, and surveys. They are actively used to identify discrepancies between income and expenses of specific taxpayers or their groups [18; 19]. Despite the possibility of obtaining sufficiently detailed information about hidden economic processes, these methods give a high probability of an estimation error, since subjective factors have a significant impact on the research results.

2. Indirect methods use indicators that reflect certain aspects of informal economic activity. They are based on the analysis of data from ministries, departments, law enforcement agencies, and use the official statistics. The group of indirect methods consists of monetary, balance sheet, resource, expert assessment, etc. These methods are widely used to assess shadow processes at the macro level $[20 ; 21]$.

3. Modeling methods allow analyzing the phenomena and processes associated with informal economic activities. The functional relationship between economic indicators and shadow processes is described by a mathematical model that makes it possible to simulate the development and estimate the volume of the shadow economy.

When applying research methods, it is necessary to take into account that there is no single method that would give accurate results for measuring the shadow economy.

According to the level of research, all methods can also be divided into macro and micro methods. This division is conditional, since all methods are actively used within the framework of various sciences, depending on the subject of research. Methods of sociology and criminology are used to study shadow relations at the micro level. Each method is applicable under certain conditions and in certain areas of social relations. To study the macro-processes of the invisible economy, the monetary method, the methods based on discrepancies between different statistical data, the method of technological coefficients, the assessment by employment indicator, etc. are used.

This study does not set the task of a detailed analysis of all methods developed by modern science for measuring the shadow component of the economy. In the authors' opinion, it is important to identify the main methods that may be applied at the regional level. Studying the dynamics and regional features of the shadow economy is important for economic development and the formation of a sustainable state policy at both regional and state levels. It should be noted that the quantitative assessment of the shadow economy at the regional level is much less common. Often, scholars describe the characteristic features of the informal economic activity in the regions and the degree of its influence on certain aspects and spheres of society. 


\section{MATERIALS AND METHODS}

Not all macro methods for measuring the shadow economy can be suitable for identifying the volume of the regional shadow economy. This is due to the specific features of the constituent entities of the Russian Federation, and problems with the availability of certain statistical data in the regions.

The main method for identifying the state of the shadow economy in the Russian Federation in the context of its regions was the method of Fedotov, Nevzorova, and Orlova. According to this methodology, the shadow activity is the only component of the gross regional product, therefore it can be included in the gross profit of the economy and gross mixed income. A significant advantage of the methodology is the use of data from the Federal State Statistics Service (Rosstat) and the Federal Tax Service [22; 23].

The size of the invisible component in the official economy of each region is determined as the discrepancy between the national accounts data, which are presented by the official statistics, and the indicators of tax reporting. This methodology was used to analyze the regional state of the shadow economy in Russia for the period of 2007-2018.

In general terms, the calculation of the size of the regional shadow economy was carried out according to the following formula:

$$
\text { GRPse }=\frac{\text { PR }-\mathrm{PR}_{\mathrm{TB}}}{\mathrm{GRP}} \cdot 100 \%
$$

where $\mathrm{GRP}_{\mathrm{SE}}$ - the share of the shadow economy in the region's GRP, \%;

$\mathrm{PR}_{\mathrm{TB}}$ - legal profit included in the tax base for corporate income tax.

Tax reporting data are more reliable; to identify legal profit, the size of the tax base for corporate income tax is used, information about which is available on the official website of the Federal Tax Service. However, in some regions (Nizhny Novgorod Region, Perm Territory, Krasnoyarsk Territory, Primorye Territory), negative values of indicators were obtained. For further analysis of the indicators, official statistics were used, and the formula for calculating the state of the shadow economy began to look like this:

$$
\text { GRPse }=\frac{\text { GRP }- \text { OR }- \text { TP }- \text { PRst }}{\text { GRP }} \cdot 100 \%
$$

where OR - official remuneration of employees (excluding its hidden component),

TP - net taxes on production (corporate property tax, transport tax and land tax paid by legal entities, license fees),

$\mathrm{PR}_{\mathrm{ST}}$ - profit reflected in the statistical reporting of organizations [22].

The results of assessing the state of the regional shadow economy in terms of tax and statistical discrepancies are not significantly different from each other. 


\section{RESULTS}

In Russia, which is divided into regions, centrifugal tendencies largely contribute to the development of informal processes and make it difficult to legalize them. In modern conditions, it is very difficult for the federal center to regulate economic activity in the regions; therefore, for the purpose of effective government regulation, it is very important to assess the state of its shadow component.

Based on the tax methodology proposed by Fedotov et al. [22], the level of the shadow economy in the regions of the Russian Federation for 2007-2018 was calculated. An analysis of the data (Table 1) showed that in most regions there was a certain pattern: for the period from 2007 to 2009, there was a decrease in the level of the shadow economy, and starting from 2009, on the contrary, there has been a gradual increase in its indicators.

For the period from 2009 to 2018, the change in the level of the shadow economy in the regions of Russia was not the same. Thus, the regions were distinguished, where during the period under review there was a slight decrease or increase in indicators.

Table 1

State of the shadow economy in the Russian regions for the period from 2006 to 2018

\begin{tabular}{|c|c|c|c|}
\hline \multirow{2}{*}{ Dynamics } & \multicolumn{3}{|c|}{ Average level of the shadow economy } \\
\hline & $20-30 \%$ & $31-50 \%$ & Over $50 \%$ \\
\hline $\begin{array}{l}\text { Negative } \\
\text { (Decrease } \\
\text { in level) }\end{array}$ & Moscow & $\begin{array}{l}\text { Arkhangelsk Region, Vologda Region, Kaliningrad } \\
\text { Region, Kemerovo Region, Kostroma Region, } \\
\text { Leningrad Region }\end{array}$ & \\
\hline Stability & $\begin{array}{l}\text { Magadan } \\
\text { Region, } \\
\text { Republic } \\
\text { of Crimea, } \\
\text { Sevastopol, } \\
\text { Republic of } \\
\text { Tyva }\end{array}$ & $\begin{array}{l}\text { Altai Territory, Vladimir Region, Volgograd Region, } \\
\text { Jewish Autonomous Region, Ivanovo Region, } \\
\text { Irkutsk Region, Kaluga Region, Kamchatka Territory, } \\
\text { Krasnodar Territory, Krasnoyarsk Territory, Kurgan } \\
\text { Region, Kursk Region, Lipetsk Region, Moscow } \\
\text { Region, Murmansk Region, Nizhny Novgorod } \\
\text { Region, Novgorod Region, Novosibirsk Region, Omsk } \\
\text { Region, Perm Territory, Primorye Territory, Pskov } \\
\text { Region, Republic of Altai, Republic of Bashkortostan, } \\
\text { Republic of Ingushetia, Republic of Mari-El, Republic } \\
\text { of Mordovia, Udmurt Republic, Republic of Sakha } \\
\text { (Yakutia), Rostov Region, Saratov Region, Smolensk } \\
\text { Region, Stavropol Region, Tambov Region, Tver } \\
\text { Region, Tula Region, Tyumen Region, Ulyanovsk } \\
\text { Region, Khabarovsk Territory, Chelyabinsk Region, } \\
\text { Chuvash Republic, Chukotka Autonomous Area, } \\
\text { Yaroslavl Region }\end{array}$ & $\begin{array}{l}\text { Karachayevo- } \\
\text { Circassian Republic, } \\
\text { Kirov Region, Penza } \\
\text { Region, Republic of } \\
\text { Adygeya, Republic of } \\
\text { Kalmykia, Sakhalin } \\
\text { Region, Khanty- } \\
\text { Mansi Autonomous } \\
\text { Area - Ugra }\end{array}$ \\
\hline $\begin{array}{l}\text { Positive } \\
\text { (Increase in } \\
\text { level) }\end{array}$ & & $\begin{array}{l}\text { Amur Region, Astrakhan Region, Belgorod Region, } \\
\text { Bryansk Region, Voronezh Region, Trans-Baikal } \\
\text { Territory, Kaliningrad Region, Novgorod Region, } \\
\text { Orenburg Region, Oryol Region, St. Petersburg, } \\
\text { Republic of Buryatia, Republic of Karelia, Republic of } \\
\text { Komi, Republic of Tatarstan, Ryazan Region, Samara } \\
\text { Region, Sverdlovsk Region, Tomsk Region }\end{array}$ & $\begin{array}{l}\text { Kabardino-Balkarian } \\
\text { Republic, Republic of } \\
\text { Dagestan, Republic } \\
\text { of North Ossetia- } \\
\text { Alania, Republic of } \\
\text { Khakassia, Chechen } \\
\text { Republic, Yamal- } \\
\text { Nenets Autonomous } \\
\text { Area }\end{array}$ \\
\hline
\end{tabular}


The table shows that the shadow economy in most regions is quite stable and varies from 30 to $50 \%$. Positive dynamics in the decline in the level of the shadow economy is observed in Moscow, the Arkhangelsk, Vologda, Kaliningrad, Kemerovo, Kostroma, and Leningrad Regions.

The growth of the shadow economy, while maintaining high values of the indicator, is noted in the regions of the North Caucasus Federal District. However, a positive trend in an increase in the shadow economy is characteristic of regions of all areas of the Russian Federation: the Amur Region, Astrakhan Region, Belgorod Region, Bryansk Region, Voronezh Region, TransBaikal Territory, Kaliningrad Region, Novgorod Region, Orenburg Region, Oryol Region, St. Petersburg, Republic of Buryatia, Republic of Karelia, Republic of Komi, Republic of Tatarstan, Ryazan Region, Samara Region, Sverdlovsk Region, Tomsk Region.

\section{DISCUSSION}

Regions of Russia differ from each other in size, population, natural resources, and features of economic development. Institutional changes taking place in Russia at the turn of the century led to the formation of a special model of shadow economic activity.

An analysis of the state of the shadow economy showed the unevenness of its development in different regions of the country.

Regional features of the shadow economy have significant structural differences and are determined by:

- geographical location;

- resource potential and possibilities of its use;

- general economic condition of the region;

- sectoral structure and general specialization of the region's economy;

- social structure of the region, its traditions, and the specific archetype formed on their basis in relation to shadow activity.

The increase in the scale of the shadow economy in most regions of the Russian Federation since 2009 can be explained by a number of factors:

1. A sharp increase in uncertainty in the political and economic spheres, which significantly affects the decision-making of economic agents. In such conditions, they reduce consumption in the current period, so that, according to the theory of permanent income, it would be possible to smooth out possible fluctuations in income and consumption in the future, increasing savings [24]. In such conditions, legal capital is "hiding in the shadows", and there is an increase in capital outflow abroad.

2. Habitualization of informal behavioral practices is a situation when informal rules replace formal rules of behavior developed in society over centuries of history and are actively used to regulate socio-economic relations. Polls conducted by VCIOM in 2008 and 2009 confirm the change in the priority of informal "rules of play" in the institutional structure of the state $(69 \%$ of respondents) over legislatively enshrined norms (20\%) [25; 26]. 
3. The state/regional regulation of the socio-economic sphere is of great importance for the development of the shadow component. Continuous changes in rules and laws, an unbearable tax burden, unavailable loans and excessive involvement of the authorities in business are just some of the problems in the economic sphere that an entrepreneur faces.

4. Corruption continues to be the main reason for the growth of the shadow economy. As part of this research, it was revealed that, when assessing the level of corruption, the opinions of Russians and experts were almost identical: $49.5 \%$ of the surveyed citizens and $47.5 \%$ of experts consider the level of corruption in modern Russian society to be high; $44.8 \%$ and $44.5 \%$, respectively, assess the level of corruption as average, $5.7 \%$ and $8 \%$ - as low [27].

5. The gap between the interests of society and the ruling elite is caused by its isolation. Integrating into the system of public administration, individual representatives are actively implementing shadow strategies in the direction of "business takeover" and/or "state takeover".

6. The rapidly developing processes of digitalization in the world lead to the erosion of geographical boundaries, which, of course, opens up new opportunities for the actors of the shadow economy. A reduction in production costs, the virtual nature of economic ties, the globalization of relations, and the movement of goods and services via the Internet are just some of the digitalization benefits, which are actively used by the shadow sector. Illusory anonymity, accessibility to a wide range of people, the absence of borders and administrative barriers, the difficulty of exercising control over the actors, the high speed of interaction and information transfer intensify shadow economic relations on the Internet. The existing regulatory framework does not take into account the key properties of the digital economy, and gaps in regulations are used to develop and strengthen shadow business in the information environment [28].

The inexhaustible economic potential of the shadow economy, modifications of its types and forms, lack of proper control, impunity and arbitrariness - all that forms an environment in which deep social and political conflicts arise, negative processes develop in all spheres of life, both in separate regions and in the entire state.

\section{CONCLUSION}

The obtained results on the assessment of the shadow economy of the constituent entities of the Russian Federation make it possible to identify the scale and trends in the development of the shadow activity in the regions, to predict its change and prospects.

The position of rejection and intense struggle against all manifestations of the shadow economy, actively declared by the authorities and business, does not diminish the urgency of the problem of the spread of hidden economic processes throughout the territory of the Russian Federation and its penetration into all spheres of society. At the same time, the current nature of the impact on shadow processes seems to be aspectual, unsystematic, and focused mainly on the identification of already occurred economic offenses or elimination of their negative 
consequences, compensation for harm, and creation of formal anti-corruption departments or structural units.

The presence of the shadow economy in all Russian regions poses a threat not only to the economic security of a particular territory but also to the safe and sustainable development of the entire country. Certain measures developed within the framework of state policy in the field of taxation, finance, education, migration, support of entrepreneurship have become a significant achievement in the countering of shadow processes; however, they did not put an end to it, because the desire to maximize and optimize profits, and sometimes even survive in a harsh market environment gives rise to new forms and ways of conducting shadow economic activities.

\section{ACKNOWLEDGMENT}

The study was supported by a grant from the Russian Foundation for Basic Research (project No. 19-010-00869 "Shadow economic activity in modern Russia: conceptualization, measurement, modeling").

\section{REFERENCES}

1. Hart, K. (1973). Informal Economy Opportunities and the Urban Employment in Ghana. Journal of Modern Africa Studies, 11(1), 61-89.

2. Mead, D., \& Morrison, C. (1996). The Informal Sector Elephant. World Development, 24(10), 1611-1619.

3. Koryagina, T. (1990). Shadow Economy in the USSR. Problems of Economics, 3, 110120.

4. Nikolaeva, M.I., \& Shevyakov, A.Yu. (1990). Shadow Economy: Methods of Analysis and Evaluation. In Economics and Mathematical Methods (pp. 926-935).

5. Gimpelson, V.E., \& Kapelyushnikov, R.I. (2014). In the Shadow of Regulation: Informality in the Russian Labor Market. Moscow: HSE Publishing House.

6. Kapelyushnikov R.I. (2012). Informal Employment in Russia: What Do Alternative Definitions Say? Moscow: HSE Publishing House.

7. Latov, Yu.V. (2019). Corruption in the Mirror of Public Opinion of Russians: Problems, Contradictions, Paradoxes. Journal of Institutional Studies, 11(4), 40-60.

8. Latov, Yu.V. (2018). Threats to the Economic Security of Regions and monitoring. In V.I. Grishina, G.Yu. Gagarina (Eds.), Regional Economy: Textbook (pp. 327-337). Moscow: KNORUS.

9. Latov, Yu.V., \& Artemiev, N.V. (2015). Institutional and Economic Reasons for the Shadowing of Small Business in Russia. Terra Economicus, 13(1), 61-72. 
10. Barsukova, S.Yu. (2012). Shadow Economy: Specificity of Phases in Conditions of Distribution. Problems of Economics, 12, 133-145.

11. Barsukova, S.Yu. (2015). Essays on the Informal Economy or 16 Shades of Gray. HSE Publishing House.

12. Kosals, L., \& Maksimova, A. (2015). Informality, Crime and Corruption in Russia: A Review of Recent Literature. Theoretical Criminology, 19(2), 278-288.

13. Radaev, V.V., Berdysheva, E.S., Konroy, N.V., \& Kotelnikova, Z.V. (2017). Analytics of Laboratory for Studies in Economic Sociology. Vol. 17: The Main Forms of Illegal Product Trafficking in the Consumer Markets of Russia and Countermeasures. Moscow: HSE Publishing House.

14.Sukhova, A.S., Gladnikova, E.V., Nagernyak, M.A., \& Roshchina, Ya.M. (2013). Informal Economy in Russian Households in the First Half of the 2000s: Domestic Work, Agricultural Production and Interfamily Transfers. Moscow: HSE Publishing House.

15. Avdiyskiy, V.I., \& Bezdenezhnykh, V.M. (2018). The Structure of Financial Flows in the Shadow Economy and the Main Methods of Their Assessment. Economy. Taxes. Law, 11(5), 6-15.

16. Schneider, F. (2016). Estimating the Size of the Shadow Economies of Highly Developed Countries. Selected New Results. CESifo DICE Report, 14(4), 44-53.

17.Schneider, F. (2017). Implausible Large Differences of the Size of the Underground Economies in Highly Developed European Countries? A Comparison of Different Estimation Methods. CESifo Working Papers. P. 6522.

18. Feige, E.L. (1990). Defining and Estimating Underground and Informal Economies. The New Institutional Economics Approach World Development, 7, 989-1002.

19. Eliseeva, I.I., Shirina, A.N., \& Kapralova, E.B. (2004). Determining the Volume of Shadow Activity Based on Macroeconomic Indicators. Questions of Statistics: Scientific and Informational Journal, 4, 18-31.

20. Ahumada, H., Alvaredo, F., \& Canavese, A. (2009). The Monetary Method to Measure the Size of the Shadow Economy: A Critical Examination of Its Use. Revue йconomique, 60(5), 1069-1078.

21. Ruge, M. (2010) Determinants and Size of the Shadow Economy - A Structural Equation Model. International Economic Journal, 24(4), 511-523.

22. Fedotov, D.Yu., Nevzorova, E.N., \& Orlova, E.N. (2020). Tax Method for Calculating the Size of the Shadow Economy in Russian Regions. International Accounting, 23(2), 224-240. Retrieved November 24, 2020, from https://doi.org/10.24891/ia.23.2.224

23. Balog, M.M., Demidova, S.E., \& Troyan, V.V. (2017). Dynamics of the Shadow Economy in the Context of Threats to the Financial Security of the Region. Economic Theory, Analysis, Practice, 6.

24. Friedman, M. (1956). A Theory of the Consumption Function. Princeton, NJ: Princeton University Press.

25. VCIOM. (2010, June 30). How Can Businesses Protect Their Rights? Press release No. 1527. 
Retrieved November 24, 2020, from http://wciom.ru/index.php?id=196\&uid=13624

26. VCIOM. (2010, June 18). The Letter of the Law or the Informal Rules of the Game: What Is More Important for Russian Business? Press Release No. 1519. Retrieved November 24, 2020, from http://wciom.ru/index.php?id=196\&uid=13593

27. Bistyaykina, D.A., \& Lizina, O.M. (2020). Corruption as a Social Problem of Society: The Results of Sociological Research. Scientific Review: Theory and Practice, 10(8), 1717-1725.

28. Mayorov, A.A. (2020). Adaptation to Digitalization in the Context of Innovative Development of the State. Creative Economy, 14(9). doi: 10.18334/ce.14.9.110846.

\section{INFORMATION ABOUT THE AUTHOR}

Olga M. Lizina (Russia, Saransk) - PhD in Economics, Associated Professor of the Department of Economics and Economic Security. Ogarev Mordovia State University. E-mail: lizinaom@yandex.ru

\section{(c) (ํ)}

Available: https://statecounsellor.wordpress.com/2020/12/01/lizina/

Received: Jun 24, 2020 | Accepted: Nov 16, 2020 | Published: Dec 1, 2020

Editor: Mohamed R. Abonazel, PhD in Statistics and Econometrics. Cairo University, EGYPT

Copyright: ( 2020 Lizina, O. This is an open access article distributed under the terms of the Creative Commons

Attribution License, which permits unrestricted use, distribution, and reproduction in any medium, provided the original author and source are credited.

Competing interests: The authors have declared that no competing interests exist. 